\title{
ANOTHER PIPING PLOVER NESTING RECORD FOR JACKFISH LAKE, SASKATCHEWAN
}

SPENCER G. SEALY, Department of Zoology, University of Manitoba, Winnipeg, Manitoba. R3T 2N2

The Piping Plover is classified presently as endangered in Canada, and in the United States it is classified as threatened throughout its range, except in the Great Lakes region where it is endangered. ${ }^{3}$ In 1984 the number of pairs of Piping Plovers estimated to be nesting in Saskatchewan was 1000 to 1250 (2000-2500 individuals), making this the largest population of Piping
Plovers in any province or state within its present breeding range. ${ }^{42}$

Renaud listed 19 and 37 localities in Saskatchewan where nesting by Piping Plovers had been confirmed, up to 1973 and 1978, respectively. ${ }^{5}{ }^{6}$ One of the localities that he listed was Jackfish Lake, $25 \mathrm{mi}$. $(40 \mathrm{~km})$ north of North Battleford. The actual nesting site was a

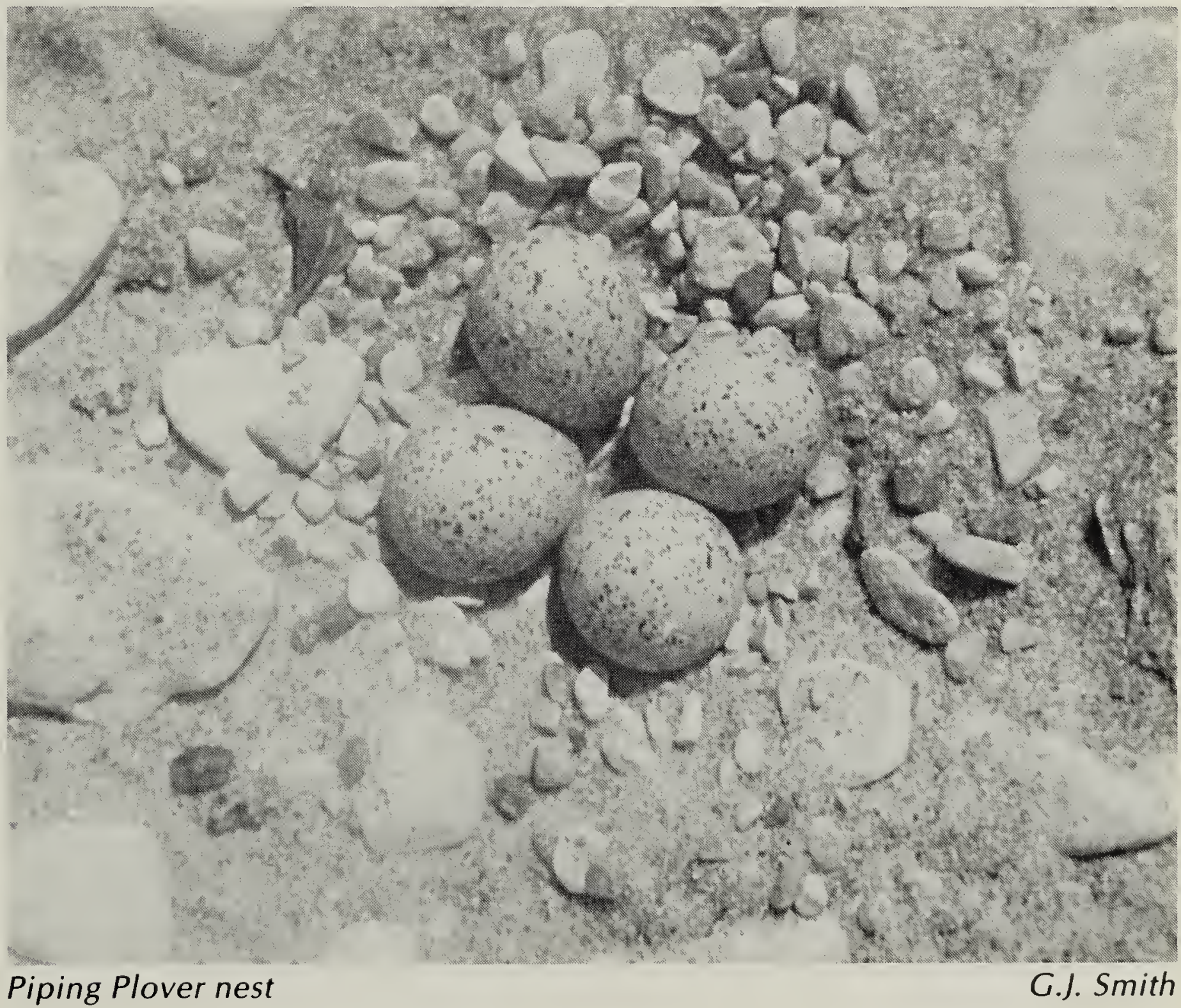


small island, unofficially named "Common Tern Island," situated in a bay at the southeastern corner of this lake, 1 $\mathrm{km}$ west of Highway \#4 and about $5 \mathrm{~km}$ south of Cochin. Renaud reported one nesting record of the Piping Plover on this island, C.S. Houston's observation of a nest containing four eggs on 13 July $1963 .{ }^{56}$

Another nesting record exists for the same island in 1962, one year prior to Houston's observation. On 4 July 1962 I visited Common Tern Island and banded 36 Common Terns. There was also a pair of Piping Plovers with at least two newly-hatched, but mobile young.

I have returned to this island only once since 1962, on 8 June 1968. Seventeen nests of the Ring-billed Gull and three Mallard nests were found but neither Piping Plovers nor Common Terns were present.

\section{Acknowledgements}

I thank Susan M. Haig for reading a draft of the manuscript and for providing up-to-date references on the status of the Piping Plover in North America.
1 HAIG, S.M. 1985. Status of the Piping Plover in Canada. National Museum of Canada, Ottawa.

${ }^{2} \mathrm{HAIG}$, S.M. and L.W. ORING 1985. Distribution and status of the Piping Plover throughout the annual cycle. J. Field Ornithol. 58:334-345.

${ }^{3}$ HAIG, S.M., D. BOWMAN, W. HARRISON, R. LOCK, L. PFANNMULLER, E. PIKE and M. RYAN 1986. Recovery plan for the Great Lakes and Northern Great Plains populations of the Piping Plover. U.S. Fish and Wildlife Service.

${ }^{4}$ HARRIS, W., G. WAPPLE, R. WAPPLE, K. DESMET and S. LAMONT 1985. Saskatchewan Piping plovers - 1984. Technical report to Sask. Nat. History Soc. and Sask. Parks and Renewable Resources, Regina, Sask.

5 RENAUD, W. 1974. Nesting Piping Plovers in Saskatchewan. Blue Jay 32:158162.

6 RENAUD, W. 1979. The Piping Plover in Saskatchewan: a status report. Blue Jay 37:90-103.

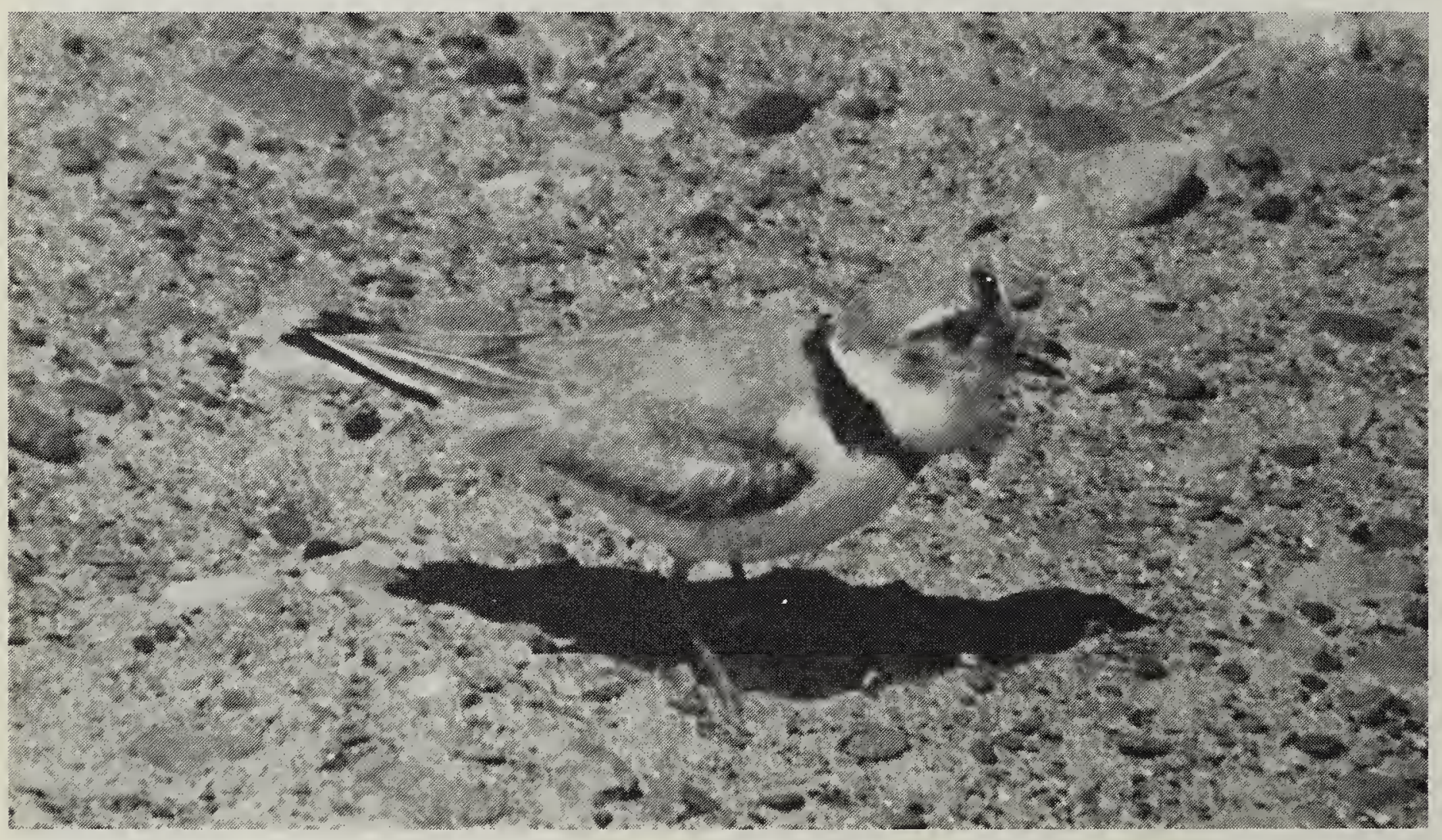

